Notre Dame Law School

NDLScholarship

Journal Articles

Publications

1975

\title{
Comparative Judicial Review and Constitutional Politics
}

Donald P. Kommers

Notre Dame Law School, donald.p.kommers.1@nd.edu

Follow this and additional works at: https://scholarship.law.nd.edu/law_faculty_scholarship

Part of the Comparative and Foreign Law Commons, Constitutional Law Commons, and the Courts Commons

\section{Recommended Citation}

Donald P. Kommers, Comparative Judicial Review and Constitutional Politics, 27 World Pol. 282 (1975) (book review).

Available at: https://scholarship.law.nd.edu/law_faculty_scholarship/1395

This Book Review is brought to you for free and open access by the Publications at NDLScholarship. It has been accepted for inclusion in Journal Articles by an authorized administrator of NDLScholarship. For more information, please contact lawdr@nd.edu. 


\title{
Review Articles \\ COMPARATIVE JUDICIAL REVIEW AND CONSTITUTIONAL POLITICS
}

\author{
By DONALD P. KOMMERS
}

Richard D. Baker, Judicial Review in Mexico: A Study of the Amparo Suit. Austin and London, University of Texas Press, 197I, 304 pp., $\$ 8.50$.

B. L. Strayer, Judicial Review of Legislation in Canada. Toronto, University of Toronto Press, 1968, 275 pp., \$15.00.

Heinz Laufer, Verfassungsgerichtsbarkeit und politischer Prozess. Tübingen, J.C.B. Mohr [Paul Siebeck], I968, 623 pp., DM 70.

Mauro Cappelletti, Judicial Review in the Contemporary World. Indianapolis, The Bobbs-Merrill Company, Inc., I971, II7 pp., $\$ 8.50$.

Edward McWhinney, Judicial Review (4th ed.). Toronto, University of Toronto Press, 1969, 270 pp., \$10.00.

Richard E. Johnston, The Effect of Judicial Review on Federal-State Relations in Australia, Canada, and the United States. Baton Rouge, Louisiana State University Press, 1969, 320 pp., \$12.00.

Thomas M. Franck, Comparative Constitutional Processes: Cases and Materials. New York, Frederick A. Praeger, 1968, 595 pp., \$16.00.

John M. Maki, Court and Constitution in Japan: Selected Supreme Court Decisions, 1948-60. Seattle, University of Washington Press, 1964, 445 pp., \$9.5o.

Glendon Schubert and David J. Danelski, eds., Comparative Judicial Behavior. New York and London, Oxford University Press, 1969, 412 pp., $\$ 7.95$.

Theodore L. Becker, Comparative Judicial Politics: The Political Functionings of Courts. Chicago, Rand McNally \& Company, 1970, 407 pp., \$6.95.

$7 \mathrm{HE}$ widespread adoption of judicial review in the world today 1 would seem to rank as a major political development of our time. It marks an important shift, at least in constitutional doctrine, from an emphasis upon the supremacy of political forces-and the principle of majority rule-at the beginning of this century, to the supremacy of written constitutions - and the principle of limited rule-at mid-century. Provisions for judicial review now appear in the constitutions of well over fifty nations, including countries of Western Europe, Latin America, Africa, and the Far East. In most of these nations, judicial review emerged as an articulate principle of post-1945 constitutions. 
Judicial review is not a twentieth-century creation, however. That political rulers are and should be subject to an order of higher law is a very old notion with deep roots in Roman and medieval political philosophy, as Mcllwain has shown. ${ }^{1}$ Associated almost exclusively with American constitutionalism in the nineteenth century, judicial review implies the obligation of courts to refuse to enforce any legislation that violates the Constitution. The authority of courts in the United States to declare laws unconstitutional was essentially a judicial invention which Americans regarded as a logical consequence of the doctrine of separation of powers. What is new about judicial review today is not merely the broad scale on which it has been adopted, but the conscious decision of constitution-makers around the globe to place the guardianship of fundamental law in judicial hands.

The books discussed below reflect the wonder of judicial scholars curious about the operation of constitutional courts and the effect of judicial review in countries other than the United States. As is to be expected at the beginning of exploratory work, these studies are enormously varied in purpose and scope. They mirror the differing perspectives of their authors, who are an interesting mix of American and foreign academicians, political scientists, legal scholars, and researchers, some committed to traditional modes of inquiry and some oriented toward quantitative studies. We might have expected, incidentally, that political scientists would be more sensitive than legal scholars to the political implications of judicial review and to the policy-making roles of constitutional courts, but such is not universally the case in the studies under review. Still, what legal scholars would want to know about judicial review would not always satisfy the curiosity of a political scientist. Undoubtedly, there is a penumbral area between law and politics where scholars in both disciplines may communicate meaningfully with one another, and I shall speak of this sphere of collaboration later on.

Six of the books discussed below are comparative (loosely defined) studies of judicial structures, decisions, or processes (Cappelletti, McWhinney, Johnston, Franck, Becker, and Schubert-Danelski); the remaining four are single-nation studies (Baker, Strayer, Maki, and Laufer). Beyond this very simple classification, the books may be divided roughly into three groups: (I) historical-analytic studies of the origin, scope, and impact of judicial review (Baker, Strayer, Cappelletti, McWhinney, and Laufer); (2) doctrinal studies-and casebooks

\footnotetext{
${ }^{1}$ Charles Howard McIlwain, Constitutionalism Ancient and Modern (Ithaca, N.Y. 1947).
} 
-in constitutional law (Franck, Johnston, and Maki); and (3) quantitative studies of judicial decision making and the judicial process (Schubert-Danelski and Becker). The time has come to take stock of these studies, to reflect on what we have learned from them, and to suggest where comparative judicial research might go from here.

\section{II}

\section{(I) HISTORICAL-ANALYTIC STUDIES}

Examinations of judicial review frequently start off with the typical lawyers' questions. Who may bring a case to a court authorized to hear constitutional complaints? What jurisdictional problems must be hurdled to gain access to the court? What cases in particular may the court hear? What principles of interpretation does the court use in deciding constitutional cases? What is the legal impact of a constitutional ruling? Exhaustive treatments of these and related questions are to be found in the studies by Strayer and by Baker, of Canada and Mexico, respectively.

In both countries, judicial review is the product of a unique set of historical circumstances. To understand the operation and functions of judicial review in Mexico and Canada today is, therefore, equivalent to knowing how the technical rules governing judicial review evolved through time. Baker maps the development and present scope of the amparo suit, which in Mexico is the principal legal tool and a highly specialized procedure used to protect individuals against the unconstitutional acts of public officials. Strayer traces the historical antecedents of judicial review in Canada, although his main concern is to describe and assess the character of constitutional litigation as applied to the review of legislation. In the best tradition of legal analysis, these studies also show how judges in both countries have used their powers of constitutional review to expand their authority beyond what appears to have been the original intent of the framers of the Constitution.

Although these books are meticulous in their attention to judicial techniques, they hardly touch in any systematic way the political dimension of judicial review. Baker and Strayer do show historically how judicial review came to be adopted in Mexico and Canada, but formal legal documents-their main source of data-say little about judicial review's social, political, and ideological determinants. Although Laufer -a German political scientist-seeks explicitly to consider the political significance of judicial review, his study of West Germany's Federal 
Constitutional Court (Bundesverfassungsgericht) is largely a narrative account of the immediate political conflicts accompanying the establishment of a constitutional tribunal in Germany and of subsequent legislative efforts to modify its structure. Laufer also considers-more than Baker or Strayer-the process of selecting justices and the political roles of the tribunal under study. However, in spite of the increasing use of interviewing and survey techniques in German political studies, Laufer tells us very little about the justices themselves, their perceptions of their judicial roles, or their attitudes towards judicial review. Although he contends that judicial review is a major influence in West Germany, the author fails to tell us exactly how that influence is to be measured.

Actually, nearly one-half of Laufer's study is a detailed analytical commentary on judicial decisions in the limited field of political parties and election law. But whether these decisions have helped to root judicial review more firmly in Germany's political soil and legal culture is a question that is hardly touched. Despite formidable trappings of scholarship-2034 footnotes and fastidiously numbered paragraphs from the beginning to the end of the 623-page volume-this is a tendentious book: it is special pleading in favor of judicial review. Moreover, the author's conclusion, that the Federal Constitutional Court is "one of the most important guarantors of the democratic order" (p. 585) in West Germany, is unsupported by empirical evidence. Judicial review and democracy, in his view, are two sides of the same coin; he seems not to allow for the possibility that judicial review might be used, as it was during the last stage of the Weimar Republic, as an illiberal and antidemocratic weapon. ${ }^{2}$

The comparative judicial scholar looking closely at these three studies will be struck more by the differences than by the similarities in the character of judicial review from nation to nation. In Mexico, the writ of amparo is designed to help a particular person with a special grievance against some public official; it is not, as Becker notes in Comparative Judicial Politics, "a strong popular check on the executive and legislative branches" (p. 210); an amparo proceeding may not even be used to protest governmental infringements on the right to property (Baker, I32). In Canada, although judicial review follows the American model, it is confined operationally to the settlement of constitutional disputes between the states (provinces) and the national government. In West

${ }^{2}$ Karl Dietrich Bracher, Die Auflösung der Weimarer Republik (Villingen-Schwarzwald I964), I93. 
Germany, judicial review extends to all legislation, and decisions of the Constitutional Court are absolutely binding on all other branches of government.

The roles of the constitutional courts in these countries also seem to vary. In Mexico, the court has served mainly to protect the citizen against arbitrary governmental action (Baker, 272); in Canada, to guard (although not always to the author's liking) the federal system (Strayer, 203-4); in West Germany, to further political democracy (Laufer, 585). Even if we discount the lack of an evidentiary base for such conclusions, these books remind us that there is likely to be a problem of equivalence in any transnational study of judicial review. Not only are the formative influences upon the development of judicial review different in each country, but so too is the formal authority conferred upon constitutional courts. Consider, for example, the field of election law. In Mexico, the courts are barred absolutely from any review of the electoral process; in West Germany, review of elections and even of the legitimacy of political parties is expressly conferred by the Basic Law; in Canada, the courts themselves have followed a policy of abstention, choosing not to adopt the American Supreme Court's policy of active intervention in electoral politics. Despite all these variations, the comparativist hungers for generalizations which will explain the appeal and uses of judicial review as a general principle, apart from its particular manifestations in various settings.

Even if Cappelletti's study of judicial review does not satisfy this hunger, it is a promising beginning. His book is a short, incisive transnational survey of the origin, scope, and agencies of judicial review, although it is confined mainly to judicial review in Europe. By treating the subject topically rather than on a country-by-country basis, Cappelletti manages to demonstrate variations in judicial review rather sharply. In his attempt to classify systems of judicial review, Cappelletti distinguishes mainly between centralized and decentralized systems of review, describes the variations within them, and, in a very general way, seeks to relate the two systems to certain features, attributes, or properties of legal (and political) systems.

At the same time, the author points to what he regards as converging trends in both centralized and decentralized systems of review. One of these trends, in his opinion, is the blurring of "long-standing distinctions between the natural law and the positive law, between precedent-oriented and statute-oriented courts, and between varying separation-of-powers theories" (p. 67). Another is the growing tendency of courts in all systems of judicial review "to stimulate a con- 
stitutional consciousness' and increasingly to play non-judicial or political roles" (pp. 67-68). Cappelletti ventures to suggest that judicial review represents a kind of modern-day universal quest for higher law principles to guide men in their search for political order. What judicial review does in fact symbolize for political elites and the general public is itself a subject worthy of cross-cultural research.

McWhinney shifts the scene to the English-speaking world, where he examines judicial review in several former British colonies, including the Republic of Ireland, Canada, Australia, India, and Pakistan. Concerned with judicial review as an agent of constitutional and political change, he is interested mainly in how judges use their authority to achieve certain policy goals. McWhinney is cognizant of the relationship between methods of judicial recruitment, judges' perceptions of their roles, judicial policy, and of both the legal and sociopolitical factors which orient judges toward judicial activism or restraint. On the whole, although acutely aware of the judiciary's limited capacity to influence the direction of a political system, McWhinney, like Cappelletti, is clearly impressed with the wide acceptance and relative success of judicial review "as a prime instrument of democratic constitutionalism" in the countries under investigation (p. 233). The author has a sharp eye for discerning new trends in the uses of judicial power, and his insights cannot easily be ignored. Still, the book's rich fund of propositions about the nature, purpose, and impact of judicial review resembles a large stew; a comparative judicial scholar ought to try his hand at boiling it down into a few workable hypotheses for crosscultural research.

\section{(2) Doctrinal STUdies}

The books by Johnston, Maki, and Franck are studies of constitutional law. Maki and Franck's works are collections of judicial decisions. Johnston's book is an analytical study of judicial decisions handed down by the high courts of the United States, Canada, and Australia. Tracing in broad strokes the historical development of federal-state relations in these countries, the author analyzes judicial opinions on intergovernmental immunity, taxation, interstate commerce, spending, and treaty making, and shows how the three tribunals have used constitutional law as a tool in limiting or expanding national or state power. Although a political scientist, Johnston is at his best when comparing legal doctrines; he is not so convincing when ranging beyond constitutional law to tell us about the actual impact of judicial decisions on federalism. For example, the author concludes that the Canadian 
Supreme Court has virtually managed to transform a federal into a confederal system of government, a result of which he disapproves. $\mathrm{He}$ also concludes that the Australian High Court has impeded the development of a healthy federalism, whereas the United States Supreme Court, in his view, has struck the proper balance between state and federal authority, mainly because American justices are pragmatic jurists and conscious of socioeconomic realities. Like Strayer and McWhinney, Johnston attributes Canadian and Australian constitutional doctrines on federalism to the formalistic legal training (and attitudes) of the judges and to their use of strict constructionist methods of constitutional interpretation. In any case, Johnston's final assessment of the impact of judicial review in Canada, Australia, and the United States is that it has been "significant" (p. 279).

Johnston's study begs complex questions about the linkage among judicial attitudes, judicial techniques, and judicial doctrines. Are variations in judicial reasoning, for example, sufficient to explain differences in the policies of constitutional courts? Problems arise, too, in the author's discussion of judicial impact. Would the historical pattern of federal-state relations have been substantially different in these countries without the constitutional jurisprudence surveyed by Johnston? Are judicial decisions dependent or independent variables? What accounts for general public acceptance of judicial settlements of federalstate conflicts? Is popular acceptance of judicial decisions denying much-needed authority to the Australian Parliament-owing, as Johnston suggests, to the public's "temperamental need to believe in the extense [sic] of a body of benevolent elders set above . . . the political struggle" or to the fact that the judges "have succeeded in "de-politicizing' their actions" (p. 286)? Johnston is correct in pointing out that judicial decisions alone "may very well present a seriously distorted view of the actual federal relationship in Canada and Australia" (p. 287); he goes on to mention, all too briefly, various informal cooperative arrangements between levels of government designed to circumvent constitutional limitations imposed by the courts.

It is appropriate to interject here that Mexico and West Germany are also federal political systems. Yet in Mexico, as Baker points out, the courts are powerless to settle federal-state conflicts; in West Germany, the Federal Constitutional Court, although originally established to play a major role as umpire of the federal system, has actually decided a very small number of federalism cases. Under what political circumstances, then, are federal-state conflicts litigated in courts? When are such conflicts negotiated outside of courts? Greater attention to the 
interplay between the judiciary and the legislative branches would probably shed light on these and other questions relevant to any examination of judicial influences on the development of federalism.

The Franck casebook deserves notice for both the scope of its coverage and the attention it gives to the judicial process in widely differing cultural settings. It is composed of a careful selection of judicial decisions from the high courts of Australia, Canada, India, England, the United States, and seventeen Asian and African countries where an inheritance of common law has been grafted onto local customary law or tribal systems of law. Concerned mainly with the scope of judicial power and fundamental rights-especially procedural rights-in newly independent states, these decisions are from appellate courts exercising authority under constitutions in large measure infused with British, American, and French constitutional principles. Whoever approaches the materials in this book with a sure footing in the constitutional law of advanced Western states will be struck by the extent to which Western concepts of constitutional law have been purposely incorporated into, or consciously rejected by, non-Western cultures. But there is an equivalence problem here too, since judicial structures vary so much from country to country, and since constitutional litigation is a relatively new activity in Africa and Asia. The recent history of the emerging nations also shows how delicate judicial review is as an instrument of limited rule, if indeed judicial review was intended to limit governmental power in these countries; it may be a lingering remnant of Anglo-Saxon influence, headed eventually for extinction.

Besides an informative introduction on judicial review in Japan, Maki's book includes twenty-six major cases in Japanese constitutional law. These cases, which I believe have not been published in English before, fall into the areas of freedom of conscience, expression, travel, and assembly, as well as defendants' rights. The inclusion of dissenting and concurring opinions provides some basis for speculating about the kind of value cleavages which appear on the Japanese Supreme Court. More important for the student of comparative politics, however, is what these decisions-and those contained in the Franck volume as well -suggest about the relationship between cultural values and constitutional law. One cannot, for example, read the obscenity case without becoming deeply conscious of moral concerns which seem rooted in Japanese culture. Yet, interestingly, the Court labored to articulate a universal moral value by which to determine obscenity. Still, one would expect any such value to be related to the dominant culture of the men holding it. Predictably, as the dissenting opinions in the obscenity case 
show, the minority was unable to accept any such universal value. But this raises the question of the relationship between basic cultural values and personal values in the making of constitutional policy-a major point of inquiry, it would seem, in any study of comparative constitutional law.

\section{(3) JUDICIAL PROCESS AND DECISION-MAKING STUDIES}

We might have expected that the remaining two books under consideration would attempt empirically to show the relationship between the judicial policies of constitutional courts and cultural values. The volume of essays edited by Schubert and Danelski, however, focuses almost exclusively on the relationship between judges' personal values and their official decisions. The articles are studies of decision making by constitutional (supreme) courts in several Asian countries (mainly Japan, India, and the Philippines), and in Canada and Australia. The search for a cross-cultural theory of judicial decision making is indeed a legitimate and immensely valuable enterprise. But some of the fascinating questions about the relationship between culture and judicial policy in certain nations (especially in Japan, Canada, and Australia), which the more conventional legal studies by Maki, Strayer, Johnston, and $\mathrm{McWhinney}$ raise, are barely addressed in this volume. It might be suggested that the quantitative techniques used in these studies limit the authors' perspective on constitutional courts. It is easy to neglect the impact of cultural values and other environmental characteristics impinging on courts in studies which employ the judicial vote as the main unit of analysis and cumulative scaling-one of several statistical methods used to relate personal values to judicial decisions-as the principal research tool.

Becker's book, the testament of a scholar in a high state of indignation with the existing literature on courts and the judicial process generally, is relevant here because of the space devoted by the author to judicial review and the study of constitutional courts. In his main line of argument, he hurls three general charges at the literature of judicial research in political science: (I) it is ethnocentric in its focus on the American judiciary; (2) it is narrow (i.e., narrowly legalistic or narrowly behavioral); and (3) it is unscientific (i.e., not cumulative). He counsels us to correct these deficiencies, in reverse order, by (I) using a structural-functional framework of analysis to (2) examine the functions performed by judicial structures in political systems on (3) a transnational basis. To achieve comparability or equivalence across national boundaries, Becker stresses the impor- 
tance of studying the judicial role, defined in terms of those judicial procedures and techniques by which impartial (i.e., judicial) decisions are reached. Judicial review enters the analysis at this point, and is defined as an aspect of judicial independence. But is the significance of judicial review to be found in the extent to which a constitutional court hands down decisions in opposition to the political branches of government? Is it to be found in the pattern of compliance with judicial mandates? Is it to be related to the frequency with which judicial review is exercised? If so, what of Ireland, where judicial review as such is seldom exercised, but where it seems nevertheless to be fully accepted as a principle of constitutional government? In short, do we exhaust the meaning or reality of judicial review for a political community by describing the empirical effects of court decisions?

Becker does not reach these questions, owing in part to his readiness to exchange the hat of a scholar for the cap of a judicial reformer. $\mathrm{He}$ attacks judicial review. The caustic cutting edge of Becker's critique slashes particularly hard into the pro-judicial review bias (which is largely assumed, not illustrated) of most research on foreign constitutional courts. No doubt we need to be reminded that judicial review is not always what it is cracked up to be and that it will not make the world safe for democracy. But the author is reckless in some of his assertions about the causes of judicial review. For example, it is simply not true, as Becker asserts, that "the influence of the United States is probably the single most important factor in bringing about the currently widespread existence of judicial review" (p. 224). The Baker, Cappelletti, Laufer, and Franck studies do not sustain this proposition. In the end, Becker proposes the abolition of judicial review in the United States and elsewhere because of its undemocratic character (pp. 383-84). Clearly, in his opinion, judicial review possesses no symbolic value for political democracies; as the author notes, judicial review is merely a "gadget" (p. $3^{85}$ ), and gadgets, after all, are disposable.

\section{III}

What generally can be said of these studies of judicial review and constitutional courts? Let us take the historical and doctrinal studies first. The random observations, contradictory statements, and disparate conclusions of the works discussed here are one indication of their theoretical deficiency. The books discussed do not conceptually relate to each other; they fail to build on each other; and they are not systematically comparative in design. Although they impart much inter- 
esting information about particular judicial decisions and the operation of certain courts, they do not add measurably to our knowledge of comparative constitutional law or of the political roles of constitutional courts. Constitutional doctrine, political culture and setting, judicial recruitment, judicial procedure and techniques, judicial decision making, conditions for judicial review, political impact of judicial review, and structural variations in the organization of constitutional courts are all covered in these volumes. But the relationship between two or more of these variables is rarely the object of systematic study, and there is an almost total failure of the literature to consider their relationship in a cross-national context.

Most of the studies considered here lack analytic structures capable of dealing reliably with these relationships even within a single national setting. Propositions about judicial review are for the most part the products of personal impressions drawn from traditional case analysis. No one has developed a framework for the systematic study of judicial policy. Although illustrations of judicial policy abound in these studies, they are mainly narrative accounts, interspersed with normative judgments, of largely episodic events.

The studies reported in the Schubert and Danelski volume, on the other hand, are exceptional for their theoretical significance and methodological sophistication, largely because the authors have tried to apply to constitutional courts in Asia statistical techniques and mathematical models successfully applied to the United States Supreme Court. The cumulative character of such studies is, of course, sufficient reason to continue experimenting with tested research methods in foreign environments. There are limits, however, to the application of behavioral methods on a comparative basis. For one thing, techniques used to study individual judicial behavior clearly cannot be applied to constitutional courts which hand down anonymous institutional opinions. Their use seems limited, too, when applied to courts-such as European constitutional courts-with an institutional bias against split decisions, even though dissenting opinions may be permitted.

A more serious limitation of behavioral techniques generally is that they restrict the scope of comparative inquiry. If it is our purpose to bring the comparative study of courts and judges into the mainstream of a developing science of comparative politics, we shall have to restore the polis to its proper place of significance in our cross-cultural research designs. We need to develop research models which will provide some means for determining the influence of unique system characteristics, such as features of the legal culture, upon judicial values and policies. Becker's 
structural-functional paradigm is at least a start, for it seeks to link courts with what they actually do for (their functions?) the political communities in which they exist. The Becker framework, however, ignores the impact or role of a judicial institution as a totality. Courts, especially constitutional courts, are more than the sum of their procedures and techniques. Courts and judges are responsible for political inputs which are not immediately derived from the judicial role as such. These inputs, including the role of courts as political symbols, need to be taken into account in studies of comparative judicial politics.

\section{IV}

Where, then, do we proceed from here? The research directions proposed below are intended to give some unity of purpose to our labors. My suggestions follow logically from the concerns of the books discussed in this article. They are not calculated to produce much in the way of general theory, if only because our first need seems to be for more exploratory work in the area of judicial review and more accurate descriptions of what constitutional courts are actually doing. Given the state of our knowledge and availability of resources, the comparative studies I suggest seem feasible of being undertaken now. They leave room also for a judicious eclecticism in the choice of research methodology. We should realize, as Arend Lijphart has recently pointed out, that the comparative method does not imply the use of any given research technique. ${ }^{8}$ Certainly, current techniques for analyzing quantified data should not alone dictate what we ought to know about constitutional courts; the tendency to place ourselves in servitude to method is always present. Let us shape our questions firstquestions which are politically relevant and intellectually interestingand then proceed to find the best means to address these questions. By directing our attention to the following, we can get on immediately with the business of comparative judicial research and begin inquiries which are most worthy of our attention.

I. We need to classify judicial review on a worldwide basis and chart its relationship to legal and political characteristics of the system. Cappelletti remarks that "in spite of its nearly universal appeal, judicial review remains an enigmatic institution" (p. 98). To unravel the enig$\mathrm{ma}$, we shall have to ask some researchable questions about judicial review. For a start it would be worthwhile, even at the level of formal constitutional organization and theory, to find out whether judicial

${ }^{3}$ Arend Lijphart, "Comparative Politics and the Comparative Method," American Political Science Review, LXv (September 197I), 682-83. 
review is commonly associated with certain legal forms, political structures, modes of judicial organization, or constitutional values. We frequently speak of judicial review in tandem with federalism, separation of powers, common-law legal systems, bills of rights, and judicial independence. But these relationships need to be clarified, for judicial review appears also in the constitutions of well over forty non-federal regimes, in several countries with civil-law legal systems, and in parliamentary as well as presidential systems of government. We also tend to equate judicial review with liberal democracy. Yet Yugoslavia, a Communist political system, has an operating constitutional court, not to mention liberal democracies which do not have judicial review. We need to go beyond Cappelletti's typology and develop a classification of variations both in the structure of constitutional courts and in the scope of judicial review in all parts of the world, and then examine the legal, political, and environmental factors which produce one type of judicial review rather than another.

A related research task is to examine the actual political conditions affecting the exercise of judicial review. One of the difficulties of the books considered in this article is that nearly all deal with countries in which judicial review is a salient characteristic of the political system and regarded as having been at least moderately successful. Our need now is for case studies of countries in which judicial review is not functioning effectively or, once adopted, has been rejected. In many parts of the world, judicial review is still little more than a formal prescription. As Franck makes clear, it has not worked in some developing nations of Africa and Asia where it is difficult enough to establish an independent judiciary, let alone tolerate judicial control of constitutionality. Experience seems to show that even in countries ruled by law within a system of partitioned power, judicial review, when newly adopted, is exercised with extreme caution if at all. We need to know more about the genealogy of judicial review in these countries so as to be able to specify the conditions under which judicial review was adopted in the first place and the conditions of its maintenance or atrophy.

2. We need intensive studies of the operation and roles of constitutional courts in individual countries. The United States Supreme Court is the only major constitutional tribunal in the world on whose internal workings and external impacts we have reasonably detailed and accurate knowledge. We are in need of similarly comprehensive studies of foreign constitutional tribunals whose organization, power, and activities can profitably be compared with the United States Supreme Court. To enhance comparability, these studies might at first be limited 
to other advanced political democracies, or even restricted to modern federal systems of government in which constitutional courts operate. A research design for the study of a particular constitutional court might focus on the input-conversion-output aspects of judicial activity. On the input side we would systematically explore the kinds of cases, petitions, or demands which come to the court; we would also want to know who goes to the court for redress, why, and under what conditions. With respect to conversion we would want to have systematic studies of the process of judicial recruitment and socialization, the activities and roles of judges, the values or "folkways" of the institution, the methods used for disposing of official business, individual and group stratagems of decision making, and norms of constitutional interpretation. On the output side we would want to know how the tribunal in question uses its power to influence public policy and to mobilize support for itself, both specific and diffuse.

We need studies of the political impact of constitutional courts most of all, for they are most relevant to a developing science of comparative politics. Surface impressions about impact need to be replaced with hard data. Systematic inquiries are required to test hypotheses about the roles and functions frequently ascribed to a court in the popular literature. We should find out how the mass public and the political elites perceive a court. How aware of the court and its decisions are these groups? How does awareness and knowledge of judicial decisions affect attitudes toward a constitutional tribunal or compliance with its rulings? Is the court really perceived as a legitimizing institution, as has often been alleged? What specific roles and functions-latent and manifest-does the court perform within the totality of the governing process? What is the court's impact in given policy areas? What are its linkages to other institutions of government, including the judicial bureaucracy? These are just some of the questions which a research design on the impact of a particular constitutional court would include. The next step in comparative research is to begin specifying how the functions, roles, and influence of constitutional courts vary from country to country, and what legal, political, cultural, or other environmental factors produce these variations. Finally, we should avoid clogging this enterprise with abstract-and, by now, tireddebates on whether judicial review is consistent with democratic theory; that track leads nowhere.

3. We need studies of comparative constitutional law. The need for systematic studies of constitutional courts and their linkages to political systems should not obviate the equally pressing need for cross-cultural 
studies of constitutional doctrine. That is an area of study which should not be the monopoly of legal scholars; it is a domain ready for collaborative work on the part of legal scholars and political theorists interested in both the idea and the phenomenon of judicial review. Of the books reviewed here, only the Johnston volume qualifies as a study in comparative constitutional law, and it is only a beginning. Actually, we have hardly begun to think comparatively about constitutional law and, until a few years ago, it was not really possible to do so. If we can overcome linguistic barriers, comparative constitutional law is an exploitable field of study, and, what is more, it promises to enrich the study and teaching of American constitutional law as well. Since 1945, West Germany, India, Japan, and Italy, to name just a few, have each created a corpus of constitutional jurisprudence which begs for comparison with American constitutional law. Comparable bodies of constitutional (or political) jurisprudence are to be found, among a few other countries (especially in Latin America), in Mexico, Canada, and Australia, recipients all, as we have seen, of still older traditions of judicial review.

It may sound a little old-fashioned or else heretical to beckon political scientists to renew their traditional concern for substantive constitutional law and policy. Personal judicial values and motivations are of course important ingredients of any assessment of constitutional policy, but for political science, moving into what is increasingly being called the post-behavioral era, comparative constitutional law can itself be a search for value (and policy) in the community of men. A large measure of intellectual excitement is to be expected from observing how the constitutional courts of different nations, with different social systems, legal cultures, and political institutions, face up to common problems of governance.

One objective of the study of comparative constitutional law is to specify those constitutional values and ideas that are commonly accepted in differing political cultures and legal systems. What shared values are reflected in the constitutional law of differing nations? Is there a set of jural postulates common to the constitutional law of culturally distinct nations? One observes, for example, a tendency on the part of courts of judicial review almost everywhere to find principles of ordered liberty, civilized conduct, simple equity, or natural justice which are not immediately derivable from the literal language of the constitutions they interpret-a phenomenon Cappelletti probably had in mind when noting the increasing convergence of positive and natural law in the constitutional law of nations. In short, what does 
judicial review symbolize in the minds of public men? Is it to be associated with declining faith in popular democracy? Does it signify political man's need for a public philosophy? Does it represent a striving after natural justice or a higher law of political obligation? What I am suggesting is that these are important questions and that they are approachable through the study of comparative constitutional law.

Another objective of the study of comparative constitutional law is to examine systematically the influence of constitutional courts upon one another. Constitutional courts are among the few places in the public life of nations today where there is serious reflection about problems of governance in the modern world. These problems are met, of course, within the limits of particular constitutional frameworks and particular political systems. Increasingly, however, constitutional courts across the world are beginning to cite each other in their opinions and to take into account each other's experiences with constitutional government. These cross-fertilizing tendencies are in need of study.

Still another objective of comparative constitutional case analysis is to investigate the role of outside influences-to the extent that these influences are specified in judicial opinions-in the shaping of constitutional doctrine. The constitutional cases of several countries (especially the United States, India, West Germany, Italy, and Canada) can now be studied from the point of view of the varying weights which constitutional courts attach to the opinions of legal scholars, historical experience, oral arguments and briefs, social and economic theories, decisions of foreign courts, as well as inside factors like the courts' own precedents. In short, we have the means to develop comparative constitutional law-and politics-into a meaningful scholarly discipline. All we need now are the scholars. 